\title{
POSSIBILITIES OF MORE PERSPECTIVE DEVELOPMENT OF THE HUNTING DESTINATION "KARAĐORĐEVO"
}

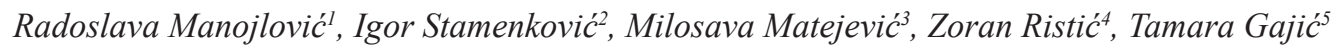

*Corresponding authorE-mail: milosava@dgt.uns.ac.rs

\begin{tabular}{|c|c|}
\hline A R T I C LE I N F O & A B S T R A C T \\
\hline Original Article & In the territory of Vojvodina, there are numerous hunting \\
\hline Received: 20 May 2020 & $\begin{array}{l}\text { grounds that are in the ranks of the most elite hunting } \\
\text { grounds in Serbia and the wider region. One of them is the }\end{array}$ \\
\hline Accepted: 20 November 2020 & hunting ground "Karađorđevo". The aim of the study was \\
\hline doi:10.5937/ekoPolj2101085M & $\begin{array}{l}\text { to determine what are the characteristics of the hunting } \\
\text { destination and elements of the hunting tourism product }\end{array}$ \\
\hline $\begin{array}{l}\text { UDC 330.34:639.1.052(497.11 } \\
\text { „Karađorđevo”) }\end{array}$ & $\begin{array}{l}\text { that are important to hunting tourist when going on a } \\
\text { journey. The goal was to determine how much the hunting }\end{array}$ \\
\hline Keywords: & $\begin{array}{l}\text { tourists are satisfied with their hunting experience in this } \\
\text { hunting area. The results showed that the most important }\end{array}$ \\
\hline $\begin{array}{l}\text { hunting tourism, tourist } \\
\text { preferences, tourist satisfaction, } \\
\text { hunting destination, rural } \\
\text { development }\end{array}$ & $\begin{array}{l}\text { was the quality of the hunting organization, and the least } \\
\text { significant were additional contents of tourist animation. } \\
\text { The natural resources of the area are the elements that } \\
\text { hunters were most satisfied with. Respondents are less }\end{array}$ \\
\hline JEL: $Z 320$ & $\begin{array}{l}\text { satisfied with the quality of accommodation and are least } \\
\text { satisfied with the complementary tourist offer. }\end{array}$ \\
\hline
\end{tabular}

(C) 2021 EA. All rights reserved.

1 Radoslava Manojlović, Ph.D. student, Department of Geography, Tourism and Hotel Management, Faculty of Sciences, University of Novi Sad, Trg Dositeja Obradovića 3, 21000 Novi Sad, Serbia, Phone: +381 214852 845, E-mail: manojlovicr.rm@gmail.com, ORCID ID (https://orcid.org/0000-0003-3277-5348)

2 Igor Stamenković, Ph.D., Assistant Professor, Department of Geography, Tourism and Hotel Management, Faculty of Sciences, University of Novi Sad, Trg Dositeja Obradovića 3, 21000 Novi Sad, Serbia, Phone: +381 214852 845, E-mail: igor.stamenkovic@dgt.uns.ac.rs, ORCID ID (https://orcid.org/0000-0001-6901-5946)

3 Milosava Matejević, Ph.D., Assistant Professor, Department of Geography, Tourism and Hotel Management, Faculty of Sciences, University of Novi Sad, Trg Dositeja Obradovića 3, 21000 Novi Sad, Serbia, Phone: +381 214852 845, E-mail: milosava@dgt.uns.ac.rs, ORCID ID (https://orcid.org/0000-0001-5345-774X)

4 Zoran Ristić, Ph.D., Full Professor, Department of Geography, Tourism and Hotel Management, Faculty of Sciences, University of Novi Sad, Trg Dositeja Obradovića 3, 21000 Novi Sad, Phone: +381 2148 52845, E-mail: zoran.ristic@dgt.uns.ac.rs, ORCID ID (https:// orcid.org/0000-0001-7273-1177)

5 Tamara Gajić, senior research, South Ural University, Institute of sport, tourism and service, Chelabinsk, Russia, Phone:+381 63565 544, E-mail: tamara.gajic.1977@gmail.com, ORCID ID (https://orcid.org/0000-0003-3016-8368) 


\section{Introduction}

Hunting tourism in Serbia, and especially in Vojvodina (the northern province of Serbia), gradually developed in the second half of the 20th century. Its peak reaches in the 1980s. During this period, when hunting-tourist traffic was the most intensive in these areas, significant foreign funds were generated through hunting tourism both for hunting grounds and for tourism organizations (Ristić, Marković, Dević, 2009; Matejević, 2017; Pantić \& Rosić, 2019). Vojvodina was a very popular hunting and tourist destination among foreign European hunters, and the largest part of the proceeds was invested in game production, marketing, import of hunting equipment, realization of scientific research projects in hunting, etc. (Gajić et al, 2018).

After the deterioration of the political stability in the country, in the mid-1990s, the number of hunting tourists dropped drastically (Dragin, 2006). This period was characterized by a decrease in the quantity and trophy quality of the game. Current political situation in Serbia is more favorable for hunting tourism development. Even though there are no ongoing official data on the numbers and revenues from annual hunting tourism in Serbia or Vojvodina region, tourist hunters are starting to return and the number of organized commercial hunts increases. However, potentials for revitalization of hunting tourism in Serbia are, still, not sufficiently exploited (Ristic et al., 2009). Hunting managers in Serbia and outfitters should work on improvement of tourist products in order to restore hunting tourism to its former state and take advantage of the tourist potential of hunting destinations and the country in general.

Hunting ground "Karađorđevo" is located in Vojvodina, about $50 \mathrm{~km}$ from Novi Sad, the regional capital. It lies along the left bank of the Danube, between $45^{\circ} 15^{\prime}$ and $45^{\circ} 22^{\prime}$ north latitude and $19^{\circ} 13^{\prime}$ and $19^{\circ} 22^{\prime}$ east longitude. This hunting ground is located in the area of the UNESCO Biosphere Reserve "Bačko Podunavlje" which surface area is 176,635 ha. "Karadjordjevo" is part of a military establishment and has a long tradition. Former Yugoslavian President Josip Broz Tito used this hunting ground as his residence where many significant meetings were held. Until 1980, the hunting ground was closed to the public, and since that time it has become open and commercial. After the political instability in the country, in the beginning of 21. century, the number of tourist hunters in the hunting ground "Karadjordjevo" is increasing, so it should be determined to what extent hunters are satisfied with the tourist product and what elements of this product need to be improved in order to achieve the optimal number of hunters in following years. The hunting ground "Karađorđevo" has retained its most important characteristics and qualities. Its most important attraction is the large number of wild animals. Hunters are most interested for trophy red deer and group hunting of wild boars.

The primary goal of the paper is to find out what are the preferences of tourist hunters when choosing a hunting tourist destination and what are determinants of hunting tourism satisfaction in hunting ground "Karađorđevo", in order to appoint the weakness and advantages of this hunting tourist destination and give guidelines for its 
development. This research was conducted on a sample on 206 respondents, and it is of importance in the context of further finding of key problems and defining strategic measures for more profitable development of hunting tourism. The results of this study may indicate to hunting workers in the hunting area how to improve their hunting tourism product.

\section{Literature review}

Hunting is a highly popular form of nature recreation, an activity enjoyed by 7 million people in Europe (Brainerd, 2007; Sharp, Wollscheid, 2009). Hunting and hunting management are a very important part of cultural heritage in many communities, as well as a significant form of business (Bauer and Giles, 2004). Hunting tourism is a journey whose main motive is to shoot certain game species (Brainerd, 2007; LeaderWilliams, 2009; Nygard \& Uthardt, 2011). Hunting activities and successful realization of hunting arrangements are conditioned by the existence of a certain game fund. This is the reason why hunting tourism is a specific form of tourism economy, where natural resources (game) are directly consumed, unlike in most other selective forms of tourism (Prentovic, 2009). Hunting tourism can have a significant positive impact on the rural community (Samuelsson, Stage, 2007; Sharp, Wollscheid, 2009; Mbaiwaa, Stronza, 2010; Naidoo et al., 2016) and can bring significant economic benefits to it (Bauer, Herr, 2004). Funds raised by hunting tourism are returned to these rural regions by direct investment in sustainable wildlife management (Leader-Williams, 2009). Brainerd (2007) defines sustainable hunting as the way of using wildlife that maintain biodiversity for present and future generations. Hunting tourism can be a form of sustainable use of wildlife resources only if it is based on scientific assessments of population numbers, and if it is competently regulated and incorruptible (Baker, 1997). If sustainable, hunting could be an important incentive for biodiversity conservation in areas that are not suitable for the development of other tourism forms (Di Minin, Leader-Williams, \& Bradshaw, 2016).

As Prentovic et al. (2012) note, specificity of demand in hunting is in its multiple layers, which is based on the specific needs of tourism-hunters. In addition to hunting, those specific needs are active leisure and recreation; staying in a healthy natural environment; enjoying the natural beauty; the exotic ambience of specific hunting areas and attractive wildlife species; education for successful hunting-tourism activities, etc. (Heberlein, Ericsson, Wollscheid, 2002; Prentovic et al, 2012; Van der Merwe, Saayman, 2013). On the other hand, the hunting-tourism product, in addition to various and trophy valuable hunting game, assumes other types of services, and above all: accommodation, food, transportation, educational services, cultural and recreational conditions and activities, and others (Prentovic et al. 2016). However, hunting represents a delicate activity in terms of safety, since various hunting firearms are used during hunting activities. Therefore, during the organization and maintenance of hunting activities, special security measures must be implemented, in order to prevent unwanted consequences during hunting and achieve the safety of all participants in the hunt (Prentović, 2014; Gačić et al., 2015). 
Hunting tourism has a potentially significant function in promoting the rural development of areas correlated with hunting tourist destinations (Prentović, Kurjački, Cvijanović, 2012; Prentović, 2014; Mbaiwa, 2017). Prentovic et al. (2016) indicate that there is high correlation of hunting with rural tourism. They explain this correlation by the fact that hunting areas are fully located in rural areas. For that reason, catering facilities of both rural and hunting tourism may offer its services to the clientele of both of these forms of tourism. The relationship of these two forms of tourism is also reflected in the field of tourist demand, since a significant number of hunter-tourists prefer to spend their stay in hunting-tourist destinations with other people, such as family members business partners, who might not be fans of hunting, but prefer exploring new and unfamiliar areas and gaining new experiences and knowledge (Prentović, et al., 2016). Prentovic et al. (2012) note that rural areas are rich in biodiversity and ecosystems, thus hunting management could represent a significant contribution to rural development, by the economic as well as social and ecological aspects. These authors state that hunting and rural tourism are multiply connected and intertwined, emphasizing that this correlation is also, manifested in the domain of supply and demand, as well as in the provision of tourism services (Prentovic et al. 2012).

Researchers in the phenomenon of hunting tourism, have explored mostly the expectations that hunters have before hunting and satisfaction after the end of hunting activities. A large number of these studies indicate that hunting satisfaction is most influenced by hunting success, that is, successful hunting of preferred game species (Decker, Brown, \& Gutierrez, 1980; Vaske, Donnelly, Heberlein, \& Shelby, 1982). However, some studies have shown that staying in a pure and unspoiled nature, being able to see game in the natural environment and testing one's own abilities can significantly affect hunter satisfaction than successful harvest itself (Hammitt, McDonald \& Patterson, 1990; Gigliotti, 2000; Schroeder et al., 2017; 2019). Some authors indicate that overall satisfaction with hunting also depends on the motivation of hunters to hunt (Kerr, 2017). On the other hand, the overall satisfaction is significantly influenced by the expectations of tourists before hunting and the fulfilled expectations (Brunke \& Hunt, 2007). Tourists with high expectations are often less satisfied after visiting a tourist destination. In fact, the difference between expectations and real experience during hunting leads to greater or lesser satisfaction (Brunke \& Hunt, 2007, 2008). Han \& Radder (2011) analyzed safari hunters` perceptions of service quality and the relationship between perceptions of service quality, satisfaction and behavioral intentions and concluded that only core service (basic benefits sought from the safari and the primary reason for the hunter provider service transaction) have a significant effect on satisfaction.

\section{Materials and methods}

Since "Karadjordjevo" hunting ground was a residential hunting ground for many years in former Yugoslavia, it was known for its attractive natural habitats, large game of high trophy value and a characteristic hunting facilities. After this hunting ground was 
opened for commercial hunting and became available to domestic and foreign hunter tourists, the attendance of the hunting ground increased. Tourist hunters were attracted to realize their hunting wishes in such a prestigious hunting ground. Therefore, the aim of the paper was to determine to what extent the hunting tourism product of this hunting destination meets the needs of hunters and whether it justifies the image that the hunting ground has. What are the preferences of tourist hunters when choosing a hunting tourist destination and what are determinants of hunting tourism satisfaction in hunting ground "Karađorđevo"?

A questionnaire consisting of three parts was used for the purposes of this research. The first part covered the socio-demographic characteristics of the respondents (gender, age, education, length of hunting experience). In the second part of the survey, the respondents stated the importance of certain elements of the hunting tourism product on a five-level Likert scale ( 1 - it does not matter to me at all; 2 - it mostly does not matter to me; 3 - I do not care; 4 - it mostly matters to me; 5 - very important to me). The items "abundance of game"; "fast service of hunting staff"; "understanding client's needs"; "ethical attitude of hunting workers towards game"; "well-trained hunting guides"; "the professionalism of hunting guides"; "successfully solving the problems of tourists"; "the hunting lodge and other facilities are fitting in the natural environment"; "the comfort of hunting lodge"; "cleanliness of accommodation (hunting lodge)" and "food and beverage quality" were chosen based on research of Han \& Radder (2011). The other attributes of hunting experience were added by authors based on interviews with hunting tourism outfitters and managers in hunting destinations.

In the third part of the questionnaire, the respondents were asked how satisfied they are with these same elements of the hunting tourism product in the "Karadjordjevo" hunting area after their stay there. The survey was conducted during 2019 in the "Karadjordjevo" hunting ground, and questionnaires were distributed by the authors of this paper. The sample consisted of 206 subjects, that is, hunters who hunted during the 2019 in the "Karadjordjevo" hunting ground.

In the analysis of the research results, the descriptive statistics methods were used first. By these methods, the description of the sample was made, that is, the description of the hunters of tourists in the Karadjordjevo hunting ground. Within the descriptive statistics, extreme values (minimum and maximum), arithmetic means, standard deviations were determined. Further statistical methods were used for data processing, such as Exploratory factor analysis (EFA), which was used to distinguish factors of preferences and satisfaction from various elements of a hunting tourism product. The frequency distribution of numerical features was examined by Skewness and Kurtosis values. Since all variables are normally distributed, parametric statistics methods ( $t$ test and F test / ANOVA) were used to determine the possible existence of statistically significant differences between different hunter groups, with respect to the extracted significance and satisfaction factors. Data were processed using SPSS (Statistical Package For Social Sciences) statistical software. 


\section{Results}

In the observed sample of traveling hunters, the largest percentage are male respondents (96.6\%), which was expected, since hunting is still considered as male activity. Regarding the age of the respondents, the most numerous respondents are hunters between 41 and 60 years of age and together they account $65.1 \%$ of the sample (table 1 ).

Table 1. Demographic characteristics of research participants

\begin{tabular}{|c|c|c|c|c|c|c|c|c|}
\hline \multicolumn{4}{|c|}{ Age structure of respondents } & \multicolumn{3}{c|}{$\begin{array}{c}\text { Educational structure of } \\
\text { respondents }\end{array}$} & \multicolumn{3}{c|}{ Length of hunting experience } \\
\hline Age (Year) & Frequency & $(\%)$ & $\begin{array}{c}\text { Educational } \\
\text { level }\end{array}$ & Frequency & $(\%)$ & $\begin{array}{c}\text { Hunting } \\
(\text { Year) }\end{array}$ & Frequency & $(\%)$ \\
\hline $21-30$ & 10 & 4.9 & High & 79 & 38.3 & $1-5$ & 22 & 10.7 \\
\hline $31-40$ & 43 & 20.9 & College & 81 & 39.3 & $6-10$ & 51 & 24.8 \\
\hline $41-50$ & 72 & 35.0 & MSc & 27 & 13.1 & $11-20$ & 87 & 42.2 \\
\hline $51-60$ & 62 & 30.1 & PhD & 19 & 9.2 & $21-30$ & 30 & 14.6 \\
\hline $21-30$ & 19 & 9.2 & - & - & - & $31-40$ & 12 & 5.8 \\
\hline$>60$ & 10 & 4.9 & - & - & - & $>40$ & 4 & 1.9 \\
\hline
\end{tabular}

Source: author's research

The majority of respondents have completed high school or college (together 77.7\%) and $80.1 \%$ of them are employed $(10.2 \%$ are retired and $6.8 \%$ are unemployed). The respondents are mostly from Serbia, $77.2 \%$ of them. The respondents are mostly from Serbia, $77.2 \%$ of them. Others are from Bosnia and Hercegovina (7.3\%), Germany (2.4\%), Slovenia (4.4\%), Montenegro (2.9\%), Croatia (1.5\%), Republic of Northern Macedonia (1.5\%), Switzerland (1\%), Hungary (0.5\%), Italy (0.5\%), Belgium $(0.5 \%)$ and Belarus $(0.5 \%)$. The respondents stated how long they have been participating in hunting activities and how long they have been engaged in hunting. Their answers were grouped into 6 groups. The majority of respondents have been hunting for more than ten years, and it can be said that the respondents were quite experienced hunters.

Factor analysis was conducted on 14 items of importance of elements of hunting destination when staying in hunting area. The internal consistency of the measuring instrument was confirmed by the obtained Cronbach's alpha coefficient $(\alpha=.761)$. The value of the Kaiser-Meyer-Olkin Measure of Sampling Adequacy (KMO) is 0.718, and the value of Bartlett's Test of Sphericity is significant $(\mathrm{p}=.000)$. Principal component analysis revealed the presence of 3 components with characteristic values over 1 . The item "The natural environment of hunting area" were below the threshold of 0.5 and has been discarded from the further analysis. The factors were rotated by Varimax rotation, with Kaiser normalization, and the obtained four factors explain a total of $57,001 \%$ of the variance, with the contribution of the first component being $29.4 \%$, the other $16.7 \%$ and third $10.8 \%$. 
Table 2. Rotated Component Matrix (importance of hunting elements)

\begin{tabular}{|c|c|c|c|}
\hline & \multicolumn{3}{|c|}{ Component } \\
\hline & 1 & 2 & 3 \\
\hline Competence and professionalism of hunting workers in hunting grounds & .865 & .043 & .085 \\
\hline Game health in hunting area & .820 & .139 & .004 \\
\hline Ethical attitude of hunting workers towards wild game & .804 & .074 & .124 \\
\hline Way of organizing hunting & .584 & .283 & -.293 \\
\hline The natural environment of the hunting area & .421 & .159 & .402 \\
\hline The ambiance hunting lodge & .143 & .773 & .175 \\
\hline Quality of accommodation (hunting lodge) & .110 & .765 & .152 \\
\hline The comfort of hunting villas and lodges & .115 & .721 & .142 \\
\hline Quality of gastronomic specialities & .088 & .710 & .107 \\
\hline Visiting natural and cultural sites in the surrounding area & .114 & .248 & .725 \\
\hline Existence of additional facilities - tourist animation programs & -.034 & -.007 & .716 \\
\hline Meeting the local population and culture & .193 & .166 & .713 \\
\hline Meeting sports and recreational needs & -.221 & .236 & .531 \\
\hline
\end{tabular}

${ }^{*}$ Extraction Method: Principal Component Analysis.

${ }^{*}$ Rotation Method: Varimax with Kaiser Normalization.

${ }^{*}$ a. Rotation converged in 5 iterations.

The first extracted factor relates to three items that speak about the quality of the organization of hunting and hunting activities in the hunting area and one item that relates to the quality and health status of the game. This factor has been named as "Hunting Organization Quality". The second extracted factor comprises a total of 4 items, which relate directly to the quality of the receptive objects and is named as "The quality of the receptive objects". The third factor is called "Complementary tourist motives" because it contains 4 items related to tourist values complementary to hunting tourism.

Table 3. Analysis of factors of importance of hunting destination elements

\begin{tabular}{|c|c|c|}
\hline \multicolumn{1}{|c|}{ Factors } & Factor saturation & $\begin{array}{c}\text { Percentage of explained } \\
\text { variance }\end{array}$ \\
\hline Factor 1 - Hunting organization quality & & $\mathbf{2 9 . 3 8 6 \%}$ \\
\hline $\begin{array}{c}\text { Competence and professionalism of hunting workers } \\
\text { in hunting grounds }\end{array}$ & .865 & \\
\hline Game health in hunting area & .820 & \\
\hline Ethical attitude of hunting workers towards wild game & .804 & \\
\hline Way of organizing hunting & .584 & $\mathbf{1 6 . 7 9 0 \%}$ \\
\hline Factor 2 - The quality of the receptive objects & & \\
\hline The ambiance hunting lodge & .773 & \\
\hline Quality of accommodation (hunting lodge) & .765 & \\
\hline The comfort of hunting villas and lodges & .721 & $\mathbf{1 0 . 8 2 5 \%}$ \\
\hline Quality of gastronomic specialties & .710 & \\
\hline Factor 3 - Complementary tourist motives & & \\
\hline $\begin{array}{l}\text { Visiting natural and cultural sites in the surrounding } \\
\text { area }\end{array}$ & .725 & \\
\hline
\end{tabular}




\begin{tabular}{|l|c|c|}
\hline \multicolumn{1}{|c|}{ Factors } & Factor saturation & $\begin{array}{c}\text { Percentage of explained } \\
\text { variance }\end{array}$ \\
\hline $\begin{array}{l}\text { Existence of additional facilities - tourist animation } \\
\text { programs }\end{array}$ & .716 & \\
\hline Meeting the local population and culture & .713 & \\
\hline Meeting sports and recreational needs & .531 & \\
\hline
\end{tabular}

Source: author's research

As can be seen in table 4, two of the three extracted factors are, on average, very significant for hunters. Factor 1 (Hunting organization quality) appears as the highest average scoring factor $(\mathrm{m}=4.59)$, while Factor 2 (The quality of the receptive objects; $\mathrm{m}=4.04$ ) is slightly lower. Factor 3 (Complementary tourist motives, $\mathrm{m}=3.22$ ) has a significantly lower power, on average.

Table 4. Descriptive statistics indicators for all 3 factors of importance $(\mathrm{N}=206)$

\begin{tabular}{|l|c|c|c|c|}
\hline & Min & Max & $\boldsymbol{m}$ & sd \\
\hline Factor 1 - Hunting organization quality & 2.75 & 5.00 & 4.5951 & .51472 \\
\hline Factor 2 - The quality of the receptive objects & 2.75 & 5.00 & 4.0388 & .52644 \\
\hline Factor 3 - Complementary tourist motives & 1.00 & 5.00 & 3.2257 & .80661 \\
\hline
\end{tabular}

$*$ Min = minimum $;$ Max $=$ maximum $; m=$ mean $; s=$ standard deviation

Using the t-test, it was found that there were no statistically significant differences between subjects of different gender in relation to all three factors. Using the F-test (ANOVA), it was found that there were no differences in the strength of the effect of the three preference factors on the subjects of different educational level.

Table 5. ANOVA - Factor 3 (Complementary tourist motives) and length of hunting experience

\begin{tabular}{|c|c|c|c|c|c|}
\hline & Sum of Squares & $\boldsymbol{d f}$ & Mean Square & $\boldsymbol{F}$ & $\boldsymbol{p}$ \\
\hline Between Groups & 7.976 & 5 & 1.595 & 2.544 & .029 \\
\hline Within Groups & 125.403 & 200 & .627 & & \\
\hline Total & 133.379 & 205 & & & \\
\hline
\end{tabular}

$* d f=$ degree of freedom; $F$ - statistic $; p=$ statistical significance

Significant statistical differences were found, using ANOVA analysis, with the Post Hoc LSD test, in Factor 3 - Complementary tourist motives $(\mathrm{F}=2,544$; $\mathrm{df}=5 ; \mathrm{p}=0.029)$ between respondents with different length of hunting experience. The magnitude of this difference, expressed by the eta square indicator, is 0.06 . Subsequent comparisons using the Tukey HSD test indicate that the mean of the hunter group with short experience $(\mathrm{m}=3.57)$ differs significantly from the mean of the hunter group with between 21 and 30 years of experience in hunting $(\mathrm{m}=2.83)$. Thus, for respondents who have been engaged in hunting for much longer complementary tourist value are of less importance. 
Table 6. Post Hoc LSD test

\begin{tabular}{|c|c|r|r|r|r|r|}
\hline \multirow{2}{*}{$\begin{array}{l}\text { (I) hunting } \\
\text { experience }\end{array}$} & \multirow{2}{*}{$\begin{array}{c}\text { (J) hunting } \\
\text { experience }\end{array}$} & $\begin{array}{c}\text { Mean Difference } \\
\text { (I-J) }\end{array}$ & \multirow{2}{*}{ Std. Error } & \multirow{2}{*}{ Sig. } & \multicolumn{2}{|c|}{$\begin{array}{c}\text { 95\% Confidence } \\
\text { Interval }\end{array}$} \\
\cline { 5 - 8 } & & & & $\begin{array}{c}\text { Lower } \\
\text { Bound }\end{array}$ & $\begin{array}{c}\text { Upper } \\
\text { Bound }\end{array}$ \\
\hline $1-5$ years & $6-10$ years & .38681 & .20198 & .396 & -.1944 & .9680 \\
\hline & $11-20$ years & .30094 & .18896 & .604 & -.2428 & .8447 \\
\hline & $21-30$ years & $.73485^{*}$ & .22226 & .014 & .0953 & 1.3744 \\
\hline & $31-40$ years & .15152 & .28417 & .995 & -.6662 & .9692 \\
\hline & $>40$ & .19318 & .43041 & .998 & -1.0453 & 1.4317 \\
\hline
\end{tabular}

* The mean difference is significant at the 0.05 level

Factor analysis was conducted on 14 items of satisfaction of hunting destination elements when staying in hunting area. Three factors are extracted in this way. The factors were rotated by Varimax rotation, with Kaiser normalization. The internal consistency of the measuring instrument was confirmed by the obtained Cronbach's alpha coefficient ( $\alpha=$ .742 ), and the sampling adequacy is indicated by the obtained .766 KMO (Kaiser-MeyerOlkin Measure of Sampling). The value of Bartlett's Test of Sphericity is significant $(\mathrm{p}=.000)$. Principal component analysis revealed the presence of 3 components with characteristic values over 1. The item "Way of organizing hunting" were below the threshold of 0.5 and has been discarded from the further analysis. and the obtained three factors explain a total of $53.37 \%$ of the variance, with the contribution of the first component being $27.64 \%$, the other $15.73 \%$ and third $10.003 \%$.

Table 7. Rotated Component Matrix (satisfaction with hunting elements)

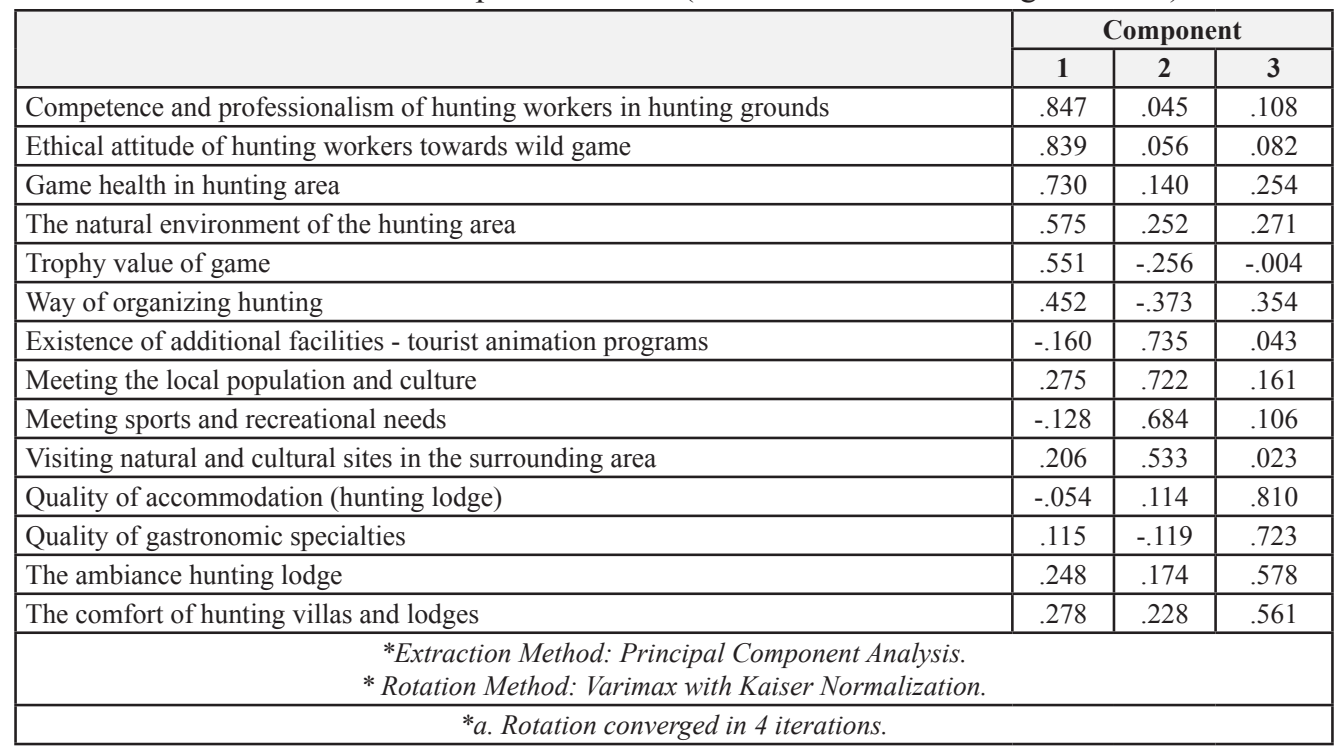

*Extraction Method: Principal Component Analysis.

* Rotation Method: Varimax with Kaiser Normalization.

*a. Rotation converged in 4 iterations. 
The first extracted factor refers to 5 items that speak about the quality of the hunting tourism offer and to what is the merit of the hunting managers in this hunting ground. This factor has been named as the "Quality of hunting tourism offer". The second extracted factor comprises a total of 4 items relating to complementary tourist values in the hunting and the surrounding area. This factor has been named as "Complementary tourist motives". The third factor is called "Quality of receptive objects", since it includes 4 items that relate directly to the quality of receptive objects.

Table 8. Analysis of factors of satisfaction with hunting destination elements

\begin{tabular}{|l|c|c|}
\hline \multicolumn{1}{|c|}{ Factors } & $\begin{array}{c}\text { Factor } \\
\text { saturation }\end{array}$ & $\begin{array}{c}\text { Percentage } \\
\text { of explained } \\
\text { variance }\end{array}$ \\
\hline Factor 1 - Quality of hunting tourism offer & & $\mathbf{2 7 . 6 4 \%}$ \\
\hline $\begin{array}{l}\text { Competence and professionalism of hunting workers in hunting } \\
\text { grounds }\end{array}$ & .847 & \\
\hline Ethical attitude of hunting workers towards wild game & .839 & \\
\hline Game health in hunting area & .730 & \\
\hline The natural environment of the hunting area & .575 & \\
\hline Trophy value of game & .584 & \\
\hline Factor 2 - Complementary tourist motives & & $\mathbf{1 5 , 7 3 \%}$ \\
\hline Existence of additional facilities - tourist animation programs & .735 & \\
\hline Meeting the local population and culture & .722 & \\
\hline Meeting sports and recreational needs & .684 & \\
\hline Visiting natural and cultural sites in the surrounding area & .533 & \\
\hline Factor 3 - Quality of receptive objects & & $\mathbf{1 0 , 0 0 3 \%}$ \\
\hline Quality of accommodation (hunting lodge) & .810 & \\
\hline Quality of gastronomic specialties & .723 & \\
\hline The ambiance hunting lodge & .578 & \\
\hline The comfort of hunting villas and lodges & .561 & \\
\hline
\end{tabular}

Source: author's research

As can be seen in Table 9, one of the three extracted factors stands out by its average value. The factor with the highest average score $(\mathrm{m}=4.30)$ is Factor 1 (Quality of hunting tourism offer). Significantly lower were Factor 3 (Quality of receptive facilities; $\mathrm{m}=3.84$ ) and Factor 2 (Complementary tourist motives, $\mathrm{m}=2.68$ ). Using the t-test and F-test (ANOVA), it was found that there were no statistically significant differences between different groups of respondents (gender, age, education, hunting experience) with respect to all three satisfaction factors. 
Table 9. Descriptive statistics indicators for all 3 factors of satisfaction $(\mathrm{N}=206)$

\begin{tabular}{|l|c|c|c|c|}
\hline & Min & Max & $\boldsymbol{m}$ & sd \\
\hline Factor 1 - Quality of hunting tourism offer & 2.60 & 5.00 & 4.3019 & .53982 \\
\hline Factor 2 - Complementary tourist motives & 1.00 & 4.75 & 2.6796 & .77374 \\
\hline Factor 3 - Quality of receptive objects & 2.50 & 5.00 & 3.8495 & .48808 \\
\hline
\end{tabular}

$*$ Min $=$ minimum $;$ Max $=$ maximum $; m=$ mean $; s=$ standard deviation

\section{Discussions}

One of the goals of the study was to establish what are the preferences of tourist hunters when choosing a hunting tourist destination. The results were somewhat different comparing to those in previous researches which have indicated that specific needs and preferences of hunting tourists are leisure and recreation, staying in a healthy natural environment, enjoying the natural beauty, the specific ambience of hunting areas, attractive wildlife species and hunting education (Heberlein, Ericsson, Wollscheid, 2002; Prentovic et al, 2012; Van der Merwe, Saayman, 2013). The results of this research showed that the respondents (consumers of the hunting and tourism product of "Karađorđevo" hunting ground) appreciate the most the quality of hunting organization. The expertise and professionalism of hunting workers in the hunting area, their ethical attitude towards wild game and the way they organize tourist hunt have proven to be the most important elements of a hunting tourism product. This shows how important it is for hunters that tourist hunting is organized in a professional manner that will, above all, ensure the safety and security of all participants in the hunt. As other research indicate how important is implementation of security measures during the organization and maintenance of hunting activities (Prentovic, 2014; Gačić et al., 2015), results in this study showed that good expertise and professionalism of hunting workers is of great value to tourist hunters. Previous researches showed that staying in a nature and watching the game in the natural environment are important factor on overall hunters' satisfaction (Hammitt, McDonald, \& Patterson, 1990; Šapić et al., 2018 Ognjanović, 2020; Gigliotti, 2000; Schroeder et al., 2017; 2019; Kral et al., 2020). However, factor analysis didn't recognize natural resources of the hunting ground (the trophy value of the game, health status of the game and the natural habitats) as important items.

In study of Han \& Radder (2011) core service showed to be of a significant effect on satisfaction. Results of this research showed that the quality of others elements of core hunting product (beside hunting workers' expertise and professionalism) was the factor that satisfied tourist hunters in great extend. Tourist hunters in hunting ground "Karadjordjevo" were very satisfied with the natural resources of the hunting ground, the trophy value of the game, its health status and the natural habitats of this game which, previously, have proven to be significant preferences of hunting tourist (Heberlein, Ericsson, Wollscheid, 2002; Prentovic et al, 2012; Van der Merwe, Saayman, 2013). The quality of service of accommodation and catering facilities has also proven to be a significant element. However, the respondents are somewhat less satisfied with the quality of the offer of accommodation and catering facilities, and least satisfied 
with the complementary tourist offer. The results showed that for the hunters are least important the additional contents of the tourist animation, that is, the tourist offer that is not closely related to the hunting contents. These complementary tourist elements are more significant only for beginner hunters and hunters with shorter hunting experience, compared to more experienced hunters, but still not of great importance. Still, it should be borne in mind that, in addition to hunting activities, hunters are not significantly interested in additional tourist programs, and less consumed it. It can be assumed this is the reason that the results showed a lower level of satisfaction with these elements.

After the hunting activities conducted by the respondents in the "Karađorđevo" hunting area, it turned out that the hunters are mostly satisfied with the quality of the hunting tourism offer of this hunting tourist destination. The expertise and professionalism of hunting workers in the "Karađorđevo" hunting area and their ethical attitude towards game proved to be of high quality, given that they were highly rated by the respondents. Considering the results of the analysis of the tourist hunters preferences, then these are very good indicators for hunting workers in hunting ground "Karađorđevo".

\section{Conclusions}

Most of previous mentioned studies in their sample included resident hunters, while the aim of our research was to investigate preferences and satisfaction of hunting tourists. There is luck of scientific research in the field of hunting tourism in the area of Balkan region and Serbia. Given that this is one of the first studies in the field of satisfaction with hunting tourism arrangements in Serbia, it can be the basis for further researches that would more accurately establish all the determinants of hunting tourist satisfaction.

Hunting ground "Karađorđevo" with adequate investments and program could become a major factor in the development of hunting tourism at the national level. Since hunting ground is located in the area of the Biosphere Reserve "Bačko Podunavlje", hunting managers could improve tourist offer by including some tourist activities within this whole area. Since, tourist hunters do not show significant interest in additional tourist offer, hunting outfitters and hunting managers could devise such an offer that tourists are interested in other tourist facilities near the hunting ground and upgrade marketing and promotional activities. Accommodation and catering facilities in hunting ground "Karadjordjevo" should be considered for upgrading and reconstruction in order to satisfied hunter tourist needs and preferences. This research may contribute to other more comprehensive and detailed research on the same topic, but at the level of whole region or Serbia.

One of limitations of the research is that the final price of a tourist product is not taken into account when selecting elements that may be of importance for hunting tourists. Further research should be directed towards analyzing a larger number of attributes of the hunting tourist product, as well as implementing analyzes that would more preciously establish specific hunting tourist product's elements that influence on overall hunting tourists' satisfaction. 


\section{Conflict of interests}

The authors declare no conflict of interest.

\section{References}

1. Bauer, J., \& Herr, A. (2004). Hunting and Fishing Tourism, In Higgenbottom, K. (eds). Wildlife Tourism: Impacts, Management and Planning. CRC for Sustainble Tourism, Common Ground Publishing, Brisbane, 57-75.

2. Brainerd, S. (2007). European Charter on Hunting and Biodiversity, Convention on the Conservation of European Wildlife Natural Habitats, Norwegian Association of Hunters \& Anglers.

3. Decker, D.J., Brown, T.J., \& Gutierrez, R.J. (1980). Further insights into the multiple- satisfactions approach for hunter management. Wildlife Society Bulletin, $8,323-331$.

4. Dragin, A. (2006). Lovno-turistički resursi Bačke-Stanje, održivi razvoj $i$ korišćenje. Univerzitet u Novom Sadu, Prirodno-matematički fakultet, Departman za geografiju, turizam i hotelijerstvo, Novi Sad.

5. Kerr, G. (2017). Marginal Satisfaction of Recreational Hunters' Red Deer Harvests, 61st AARES Annual Conference, Brisbane Conference and Entertainment Centre, Brisbane, 8-10 February 2017.

6. Kral, P., Janoskova, K., Lazaroiu, G., \& Suler, P. (2020). Impact of Selected SocioDemographic Characteristics on Branded Product Preference in Consumer Markets. Management \& Marketing. Challenges for the Knowledge Society, 15(4), 570-586. https://doi: 10.2478/mmcks-2020-0033

7. Gajić, T., Penić, M., Vujko, A., \& Petrović, M.D. (2018). Development Perspectives of Rural Tourism Policy - Comparative Study of Rural Tourism Competitiveness Based on Perceptions of Tourism Workers in Slovenia and Serbia. Eastern European Countryside, 24(1), 144-154. https://doi.org/10.2478/eec-2018-0007

8. Gigliotti, L.M. (2000). A classification scheme to better understand satisfaction of Black Hills deer hunters: The role of harvest success. Human Dimensions of Wildlife, 5, 32-51. https://doi.org/10.1080/10871200009359171

9. Hammitt, W., McDonald, C.D., \& Patterson, M.E. (1990). Determinants of multiple satisfaction for deer hunting. Wildlife Society Bulletin, 18, 331-337.

10.Mbaiwa, J. (2017). Effects of the safari hunting tourism ban on rural livelihoods and wildlife conservation in Northern Botswana, South African Geographical Journal, 100(1), 41-61, https://doi.org/10.1080/03736245.2017.1299639

11. Leader-Williams, N. (2009). Conservation and hunting: Friends or Foes? in Barney Dickson,Jonathan Hutton,Bill Adams 2009. Recreational Hunting, Conservation and Rural Livelihoods: Science and Practice, $1^{\text {st }}$ edition, Blackwell Publishing. 
12. Matejevic, M. (2017). Cynological aspects of hunting tourism in Serbia, Department of geography, tourism and hotel management, Faculty of Science [in Serbian: Matejevic, M. (2017). Kinološki aspekti lovnog turizma u Srbiji, Departman za geografiju, turizam i hotelijerstvo, Prirodno-matematički fakultet, Univerzitet u Novom Sadu].

13.Mbaiwaa, J.E., \& Stronza, A.L. (2010). The effects of tourism development on rural livelihoods in the Okavango Delta, Botswana. Journal of Sustainable Tourism, 18(5), 635-656 https://doi.org/10.1080/09669581003653500

14.Naidoo, R., Weaver. L.C., Diggle, R.W., Matongo, G., Stuart-Hill, G., \& Thouless, C. (2016). Complementary benefits of tourism and hunting to communal conservancies in Namibia. Conservation Biology, 30(3), 628-638, https://doi.org/10.1111/ cobi. 12643

15.Nygard, M., \& Uthardt, L. (2011). Opportunity or threat? Finnish hunters' attitudes to hunting tourism. Journal of Sustainable Tourism, 19(3), 383-401. https://doi.org /10.1080/09669582.2010.524701

16.Ognjanović, J. (2020). Employer brand and workforce performance in hotel companies. Hotel and Tourism Management, 8(2), 65-78. https://doi.org/10.5937/ menhottur20020650

17.Pantić, N., \& Rosić, M. (2019). Karakteristike projektovanja ekoloških nanada. Održivi razvoj, 1(1), 29-42. https://doi.org/10.5937/OdrRaz1901029P

18.Prentović, R. (2008). Correlation of hunting and rural tourism in Vojvodina, Researches Review of the Department of Geography, Tourism and Hotel Management, 37, 110-121. [in Serbian: Prentović, R. (2008). Korelacija lovnog i ruralnog turizma u Vojvodini, Zbornik radova Departmana za geografju, turizam i hotelijerstvo, 37 , Departman za geografju, turizam i hotelijerstvo, 110-121 Novi Sad].

19.Prentović, R. (2009). Agency business in hunting tourism. Researches Review of the Department of Geography, Tourism and Hotel Management, 38, 210 - 227 [in Serbian: Prentović, R. (2009). Agencijsko poslovanje u lovnom turizmu. Zbornik radova Departmana za geografju, turizam i hotelijerstvo, 38, 210 - 227].

20.Prentović, R. (2014). Hunting tourism activities, Department of Geography, Tourism and Hotel Management, Faculty of Science [in Serbian: Prentović, R. (2014). Lovnoturistička delatnost, Departman za geografiju, turizam i hotelijerstvo, Prirodno-matematički fakultet, Novi Sad].

21.Prentović, R., Kurjački, A., \& Cvijanović, D. (2012). Hunting in rural areas of Backa. Economics Of Agriculture, 59(3), 385-400.

22.Ristic, Z., Marković, V., \& Devic, M. (2009). Development of Hunting Tourism in Vojvodina. Geographica Pannonica, 13(3), 105-114. https://doi.org/10.5937/ GeoPan0903105R 
23.Han, X., \& Radder, L. (2011). Measurement And Consequences Of U.S. Tourists Perceptions Of Service Quality: A South African Hunting Safari Case Study. International Business \& Economics Research Journal, 10(5), https://doi. org/10.19030/iber.v10i5.4229

24.Samuelsson, E., \& Stage, J. (2007). The size and distribution of the economic impacts of Namibian hunting tourism. South African Journal of Wildlife Research, 37(1), 41-52. https://doi.org/10.3957/0379-4369-37.1.41

25.Schroeder, S., Cornicelli, L., Fulton, D., \& Merchant, S. (2017). Explicit versus implicit motivations: Clarifying how experiences affect turkey hunter satisfaction using revised importance-performance, importance grid, and penalty-rewardcontrast analyses. Human Dimensions of Wildlife, 23(1). https://doi.org/10.1080/10 871209.2018.1385112

26. Schroeder, S., Cornicelli, L., Fulton, D., \& Merchant, S. (2019). The influence of motivation versus experience on recreation satisfaction: How appreciative versus achievement-oriented recreation experience preferences relate to hunter satisfaction. Journal of Leisure Research, 50(2). https://doi.org/10.1080/00222216.2018.15575 02

27.Sharp, R., \& Wollscheid, K.U. (2009). Recreational Hunting in North America, Europe and Australia, in Dickson, B., Hutton, J., Adams, B. 2009. Recreational Hunting, Conservation and Rural Livelihoods: Science and Practice, $1^{\text {st }}$ edition, Blackwell Publishing.

28.Šapić, S., Furtula, S., \& Durkalić, D. (2018). Prestige and national identity as predictors of food products purchase. Economics of Agriculture, 65(2), 643-657., https://doi:10.5937/ekoPolj1802643S

29.Vaske, J.J., Donnelly, M.P., Heberlein, T.A., \& Shelby, B. (1982). Differences in reported satisfaction ratings by consumptive and non consumptive recreationists. Journal of Leisure Research, 14, 195-206. 